\title{
Seasonal Changes in Soil and Air Temperature at Three Locations in Puerto Rico, 1963-67'
}

\author{
M. A. Lugo-López and Modesto Capiel ${ }^{2}$
}

INTRODUCTION

Soil temperature is one of the major factors affecting growth of plants and biological activity of soils. The rate of decomposition of organic matter and organic nitrogen mineralization increases with increasing temperature. The intensity of other important biological processes occurring in the soil also varies with soil temperature (1). Soil temperature affects plant growth $(2,4,6)$. Germination, seedling emergence, sprouting, growth of underground plant organs, growth of shoots, vegetative growth, crop quality, plant injury and plant disease all are affected by soil temperature.

The distribution, growth and number of microorganisms, the activity of legume bacteria and general purpose heterotrophic organisms, ammonification, nitrification, and even soil aggregation, are influenced by soil temperature. On the other hand, soil and crop management affect soil temperature (1).

No data has been published concerning soil temperature in Puerto Rico. Therefore, this paper is, to our knowledge, the first contribution to this area of soil science in Puerto Rica. As such, it summarizes data on soil temperature obtained from 1963 through 1967 at three locations in Puerto Rico. It is hoped the information presented herein may open new avenues of research on this important soil factor.

\section{SOIL TEMPERATURE DEFINED}

Soil temperature is the thermal property of soils accounting for their heat content. Heating and cooling are cyclically involved in establishing the daily temperature span. The major factor influencing heating is solar radiation, depending on the nature of the soil cover, color, slope and moisture content of the soil.

1 Manuscript submitted to Editorial Board October 1, 1971.

2 Soil Scientist and Associate Soil Bcientist, respectively, Agricultural Experiment Station, University of Puerto Rico, Mayagüez Campus, Rio Piedras and Mayagüez, P.R. The original data used in this study were obtained under Station Project, C-411. The Bioclimate of Puerto Rico. Appreciation is expressed to Mr. Juan Pastor Rodríguez, Mr. Alberto Amy, and Mr. Alfonso Riera, past project leaders and custodians of the data; also to the several Station staff members, clerks and others involved in collecting the data at the Río Piedras, Lajas and Fortuna Station farms. We are particularly grateful to Mr. Mariano Antoni for his valuable help in the statistical analyses of the data. 
In the cooling process of soils, long-wave back radiation, convection and evaporation play the major roles, depending also on the same factors influencing the heating process. The heat cycle is less pronounced with depth, especially on close-cropped soils. Rainfall and soil management practices, including drainage, irrigation and tillage, exert great effect on diurnal temperature cycles. As in air temperature cycles, seasonal spans are much less pronounced than daily spans.

\section{MEASUREMENTS AND METHODS}

Daily soil temperature data were taken for various periods in each month throughout the 5-year period 1963-67 at three locations: Río Piedras in northern Puerto Rico, Lajas in the southwest, and Fortuna in the south. Maximum and minimum soil temperature data were taken at 2- and 8-inch depths, obtained from continuous soil temperature recording. These were averaged, summing up different lengths of time of the corresponding month throughout the 5-year period, and finally dividing by the total number of days. These varied from 43 to 122 days of a possible total of around 150 days (30 days per month throughout 5 years). The data finally were organized by months. Maximum and minimum air temperature data were treated in the same way. Mean air temperature then was calculated by averaging the maximum and minimum air temperatures during the same periods soil temperature data were collected. The mean daily rainfall also was calculated coincident with the soil and air temperature data.

Soil-air temperature relationships under sod and bare soil conditions were analysed by simple linear regression. Soil temperature data for Lajas and Río Piedras were taken under bare soil; that for Fortuna under short grass (Cynodon dactylon).

The soil at Rio Piedras, where the weather data were collected, has a 0 to 7-inch dark brown silty clay loam surface; weak fine granular structure; firm when moist, slightly sticky and plastic when wet; strongly acid; with few manganese and iron concretions. It is somewhat poorly drained, with slow surface drainage and slowly permeable $(5,7)$.

The soil at Lajas has a very dark brown clay surface 7 -inches deep with weak medium granular structure; firm, slightly sticky and plastic. It is moderately well drained, with moderately slow permeability and slow to medium rate of run-off $(3,7)$.

The soil at Fortuna has a 10-inch surface soil which is friable, firm and slightly cohesive, calcareous brown or dark-brown clay. It is plastic when wet and large cracks appear on the surface when it dries (5).

\section{RESULTS AND DISCUSSION}

A summary of the data on soil temperature at Río Piedras, Lajas, and Fortuna is given in table 1 . It may be observed that bare soil conditions 
TABLE 1.-Mean maximum and minimum soil temperatures registered al 2-and 8-inch depths at three locations in Puerto Rico averaged for different lengths of time on every month along a 5-year period (1969-67)

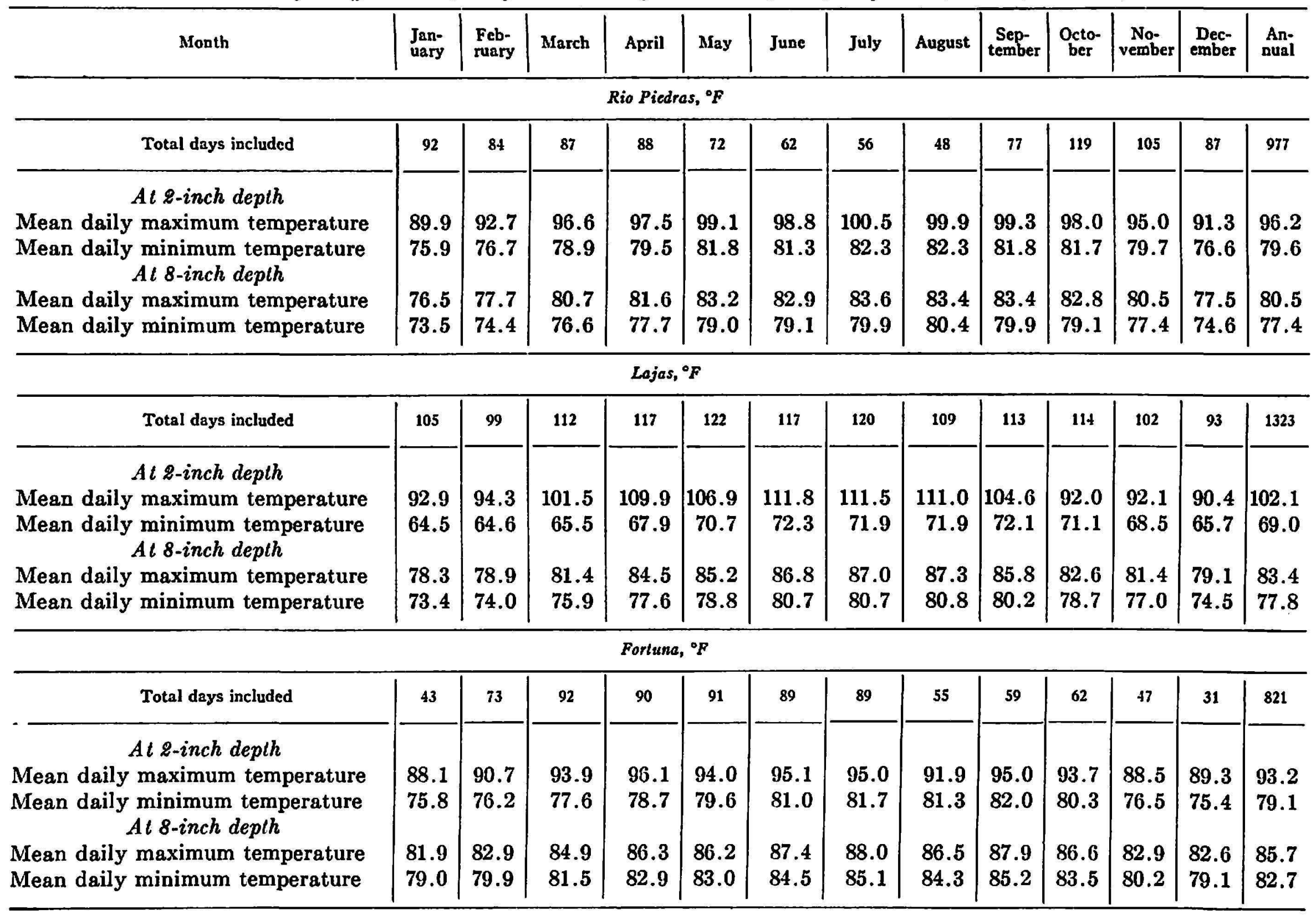


(Lajas), as compared to sod covered (Fortuna), leads to wider differences between the maximum and minimum soil temperature at 2 inches. The mean annual differences between the extremes are $32.7^{\circ}, 16.7^{\circ}$ and $13.9^{\circ} \mathrm{F}$. at Lajas, Río Piedras and Fortuna, respectively. March to August exhibit the greatest maximum-minimum differences in the three areas. In April, the gap at Lajas is $42^{\circ}$ (at the 2-inch depth). However, even though bare soils exhibit the widest difference between maximum and minimum soil temperature at $\mathbf{2}$ inches, Lajas maintains at least twice as much difference through the year as Rio Piedras, the latter station being more similar in this respect to Fortuna than to Lajas. This is to be expected because the soil at Rio Piedras maintains a greater heat capacity than that of Lajas as a result of heavier and more consistent rainfall through the year. Thus, on the drier soil, temperatures increase more rapidly during the day and decrease faster at night. On the other hand, the fact that the soil is under grass cover at Fortuna compensates somewhat and the temperature at 2 inches approaches that of Rio Piedras (bare soil). If the soil temperature at Fortuna had been taken in an exposed soil surface, the maximum temperature would probably have been higher than at Lajas. However, the minimum soil temperature before sunrise probably does not decrease as much as at Lajas because the sea breeze counteracts the upward sensible heat flux to some extent at Fortuna. In the Lajas area, the sea breeze does not interfere with the nighttime cooling of the daily temperature cycle.

The maximum-minimum difference in soil temperature at the 8-inch depth is roughly one-fifth the magnitude at the 2-inch depth. However, the three stations maintain the same relationships, i.e., Lajas differences exceed Rio Piedras; the latter exceeds Fortuna. But Río Piedras maximumminimum differences again are closer to those at Fortuna than at Lajas. The same explanations for differences at the 2-inch depth account for those at the 8-inch depth. As we get farther from the soil-air interface the differences become less marked and are further minimized under sod cover.

The maximum soil temperatures at the 8-inch depth at Fortuna exceed those at Lajas and Rio Piedras. The main reason this is so is that the 2-inch maximum is much higher at Lajas than at Fortuna where a certain amount of net soil heat is stored on a daily basis, largely on account of the sod cover barrier. This net storage increases to a given shallow depth, and the soil temperature at that depth, in this case 8 inches, begins the next day with much higher values (over 13 degrees as an average). Although the 8inch soil temperature at Lajas exhibits a steeper increase during the day than at Fortuna, because of the bare soil conditions, by the time both exhibit their maximum (between the fourteenth to the fifteenth hours) the 8inch soil temperature at Fortuna is still higher. 
Data on air temperature and rainfall for the period 1963-67 at the same three locations, where data on soil temperature were taken for the same period, are shown in table 2. Rainfall data is included in table 2 , because just as the added soil moisture (derived from rainfall in this study) contributes to explain differences in soil temperature, air humidity regulates air temperature. Thus, with drier atmosphere, Lajas and Fortuna exhibit the greater maximum temperatures. This is because a larger proportion of the energy flux directly from the sun, atmosphere or backward radiation is converted to sensible heat at Fortuna and Lajas, while the energy partitioning at Rio Piedras allows for greater proportions of latent heat of vaporization.

Sod cover furnishes only a localized effect on soil temperature at Fortuna. However this condition is not exhibited on the air temperature because the reported air temperature represents a macroscale in which the surroundings have both bare and grass cover in the three areas. Thus, the air temperature attains greater similarity among the three areas, with the humidity of the air exerting a buffer effect to changes in air temperature. That the minimum air temperature was higher at Fortuna than at Lajas probably is due to the sea breeze effect as previously mentioned.

Figure 1 helps visualize and better trace the data presented in tables 1 and 2. Only the soil temperature data at the 2-inch depth were plotted. It can be readily observed that only Lajas has mean maximum soil temperatures at the 2 -inch depth well above $100^{\circ} \mathrm{F}$. during the major part of the year. It may also be observed that the higher mean maximum soil temperature at Lajas on a daily basis tends to coincide with the lowest mean rainfall. This generally is the case under bare soil conditions.

From October to February, under short day conditions, the low rainfall does not have significant effect in increasing soil temperature at 2 inches. Although a dry soil has less heat capacity, allowing temperature to rise faster, less solar radiation is available to be converted into sensible heat as the days become shorter.

Figure 1 suggests that bare soil conditions contribute to establish wider differences between maximum and minimum soil temperatures than does decreasing soil moisture. This is the case when Río Piedras (bare soil) and Fortuna (low precipitation) are compared.

A further step was taken by investigating the soil-air temperature relationships by simple linear regression analysis. The combined Lajas and Río Piedras mean soil temperature range (maximum less minimum) at 2 inches, obtained for bare soil conditions, were compared with the corresponding air temperature range. The correlation coefficient was found to be 0.868 ; significant at the one-percent level. On the other hand, when establishing the same comparison for Fortuna, under sod cover, the relationship between the soil and air temperature range at 2 inches was found to be non-signif- 
TABLE 2.-Mean maximum and minimum air lemperature registered al three localions in Puerto Rico, averaged for different lengths of time on every month along a 5 -year period (1968-67). The mean daily rainfall for the several periods is also included

\begin{tabular}{|c|c|c|c|c|c|c|c|c|c|c|c|c|c|}
\hline Month & $\underset{\text { uary }}{\text { Jan- }}$ & $\begin{array}{l}\text { Feb- } \\
\text { ruary }\end{array}$ & March & April & May & June & July & August & $\underset{\text { tember }}{\text { Sep- }}$ & $\begin{array}{l}\text { Octo- } \\
\text { ber }\end{array}$ & $\begin{array}{c}\text { No- } \\
\text { vember }\end{array}$ & $\begin{array}{c}\text { Dec- } \\
\text { ember }\end{array}$ & $\begin{array}{c}\text { An- } \\
\text { nual }\end{array}$ \\
\hline \multicolumn{14}{|c|}{ Rio Piedras, ${ }^{\circ} \mathrm{F}$} \\
\hline Total days included & 92 & 84 & 87 & 88 & 72 & 62 & 5 & 48 & 77 & 119 & 105 & 87 & 977 \\
\hline $\begin{array}{l}\text { Mean daily maximum temperature } \\
\text { Mean daily minimum temperature } \\
\text { Mean daily rainfall, inches }\end{array}$ & $\begin{array}{r}82.4 \\
65.5 \\
.10\end{array}$ & $\begin{array}{r}83.4 \\
66.1 \\
.06\end{array}$ & $\begin{array}{r}84.9 \\
67.6 \\
.09\end{array}$ & $\begin{array}{r}84.8 \\
68.2 \\
.22\end{array}$ & $\begin{array}{r}86.5 \\
70.7 \\
.16\end{array}$ & $\begin{array}{r}87.1 \\
71.1 \\
.28\end{array}$ & $\begin{array}{l}87.1 \\
72.3 \\
.24\end{array}$ & $\begin{array}{r}87.3 \\
72.8 \\
.17\end{array}$ & $\begin{array}{r}88.1 \\
72.1 \\
.25\end{array}$ & $\begin{array}{r}87.9 \\
71.4 \\
.16\end{array}$ & $\begin{array}{r}85.8 \\
69.2 \\
.11\end{array}$ & $\begin{array}{r}83.8 \\
67.1 \\
.17\end{array}$ & $\begin{array}{r}85.6 \\
69.2 \\
0.17\end{array}$ \\
\hline \multicolumn{14}{|c|}{ Lajas, ${ }^{\circ} \mathrm{F}$} \\
\hline Total days included & 105 & 99 & 112 & 117 & 122 & 117 & 120 & 109 & 113 & 114 & 102 & 93 & 1323 \\
\hline $\begin{array}{l}\text { Mean daily maximum temperature } \\
\text { Mean daily minimum temperature } \\
\text { Mean daily rainfall, inches }\end{array}$ & $\begin{array}{r}85.9 \\
60.4 \\
.05\end{array} \mid$ & $\begin{array}{r}86.5 \\
61.1 \\
.05\end{array} \mid$ & $\begin{array}{r}87.0 \\
61.5 \\
.03\end{array}$ & $\begin{array}{r}87.2 \\
63.3 \\
.09\end{array}$ & $\begin{array}{r}88.3 \\
67.2 \\
.12\end{array}$ & $\begin{array}{r}90.3 \\
68.3 \\
.05\end{array}$ & $\begin{array}{r}90.5 \\
68.3 \\
.12\end{array}$ & $\begin{array}{r}90.1 \\
68.3 \\
.09\end{array}$ & $\begin{array}{r}89.8 \\
68.5 \\
.22\end{array}$ & $\begin{array}{r}89.1 \\
68.0 \\
.18\end{array}$ & $\begin{array}{r}87.0 \\
65.2 \\
.10\end{array}$ & $\begin{array}{r}86.6 \\
62.1 \\
.07\end{array}$ & $\begin{array}{r}88.3 \\
65.3 \\
0.10\end{array}$ \\
\hline \multicolumn{14}{|c|}{ Fortuna, ${ }^{\circ} \boldsymbol{F}$} \\
\hline Total days included & 43 & 73 & 92 & 90 & 91 & 89 & 89 & 55 & 59 & 62 & 47 & 31 & 821 \\
\hline $\begin{array}{l}\text { Mean daily maximum temperature } \\
\text { Mean daily minimum temperature } \\
\text { Mean daily rainfall, inches }\end{array}$ & $\begin{array}{r}85.5 \\
67.1 \\
.07\end{array}$ & $\begin{array}{r}85.6 \\
65.3 \\
.02\end{array}$ & $\begin{array}{r}86.6 \\
65.3 \\
.03\end{array}$ & $\begin{array}{r}86.9 \\
66.3 \\
.04\end{array}$ & $\begin{array}{r}87.7 \\
69.5 \\
.11\end{array}$ & $\begin{array}{r}88.9 \\
72.0 \\
.07\end{array}$ & $\begin{array}{r}90.6 \\
72.1 \\
.08\end{array}$ & $\begin{array}{r}89.7 \\
71.5 \\
.12\end{array}$ & $\begin{array}{r}91.0 \\
71.5 \\
.06\end{array}$ & $\begin{array}{r}89.7 \\
70.5 \\
.09\end{array}$ & $\begin{array}{r}87.7 \\
67.9 \\
.10\end{array}$ & $\begin{array}{r}86.0 \\
65.6 \\
.06\end{array}$ & $\begin{array}{r}88.1 \\
68.8 \\
0.07\end{array}$ \\
\hline
\end{tabular}


cant, $r=0.531$. At the 8-inch depth, the comparison was still highly significant for Lajas and Río Piedras, $r=0.756$, but not so for Fortuna, $r=0.505$. The more significant soil-air relationships of the combined Lajas and Rio Piedras data can be explained by the absence of an interfering layer (sod cover) at these two areas. The sod at Fortuna absorbs some of the solar energy, besides reflecting a greater amount of energy than under bare soil conditions. Thus, the solar energy partitioning at the soil-air interface maintains a closer relationship between these two bodies than when a sod cover redistributes the total solar energy received.

According to Baver (1) "Since the sun is the source of practically all the

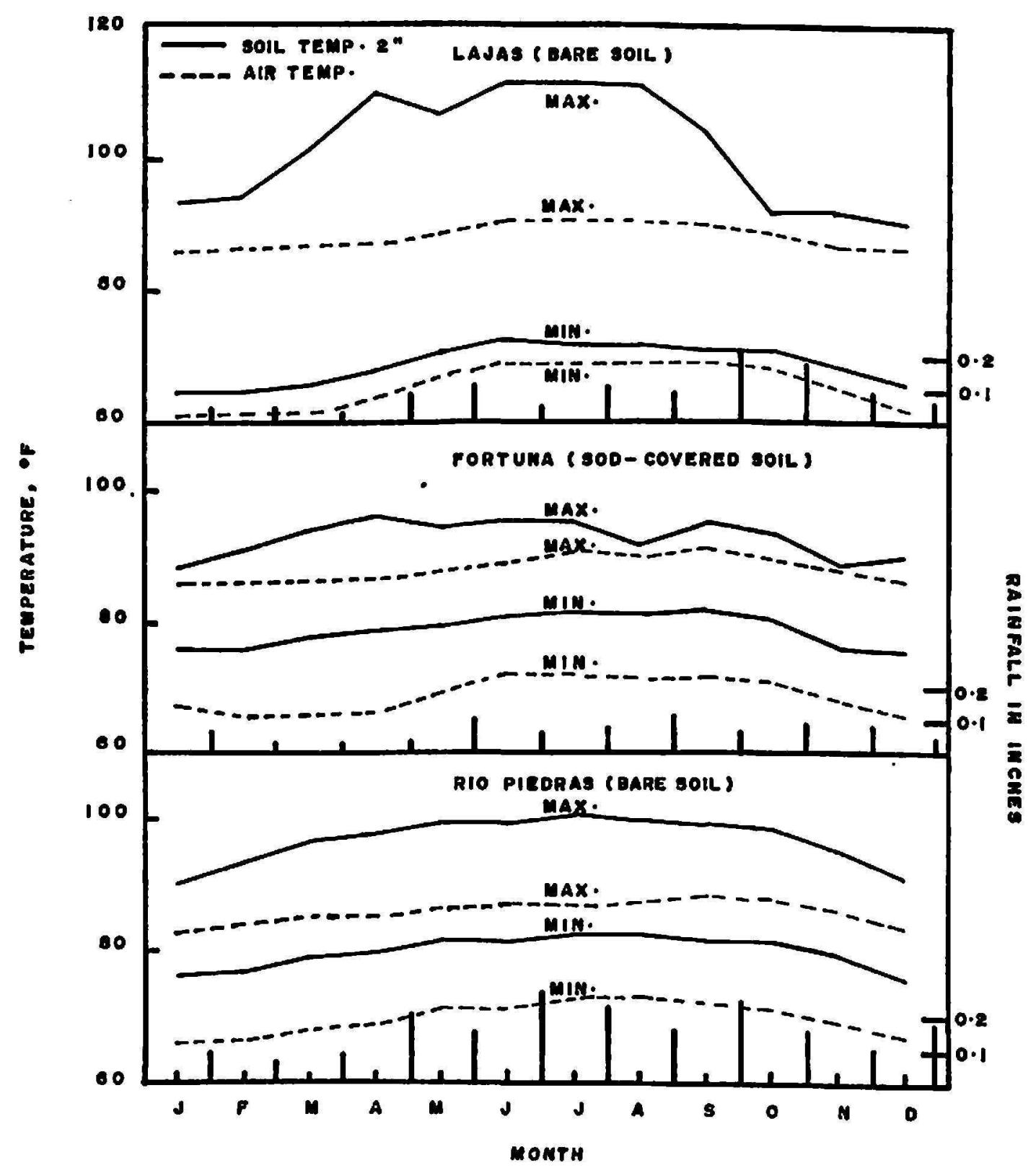

FIG. 1.-Monthly variations in soil temperature at 2-inch depth at three locations in Puerto Rico. 
heat that enters the soil, there will always be a movement of heat downward during the time that the sun's rays strike the soil. If the surface of the soil becomes cooler than the subsurface during the night, there will be a movement of heat toward the surface and into the atmosphere, that is, if the

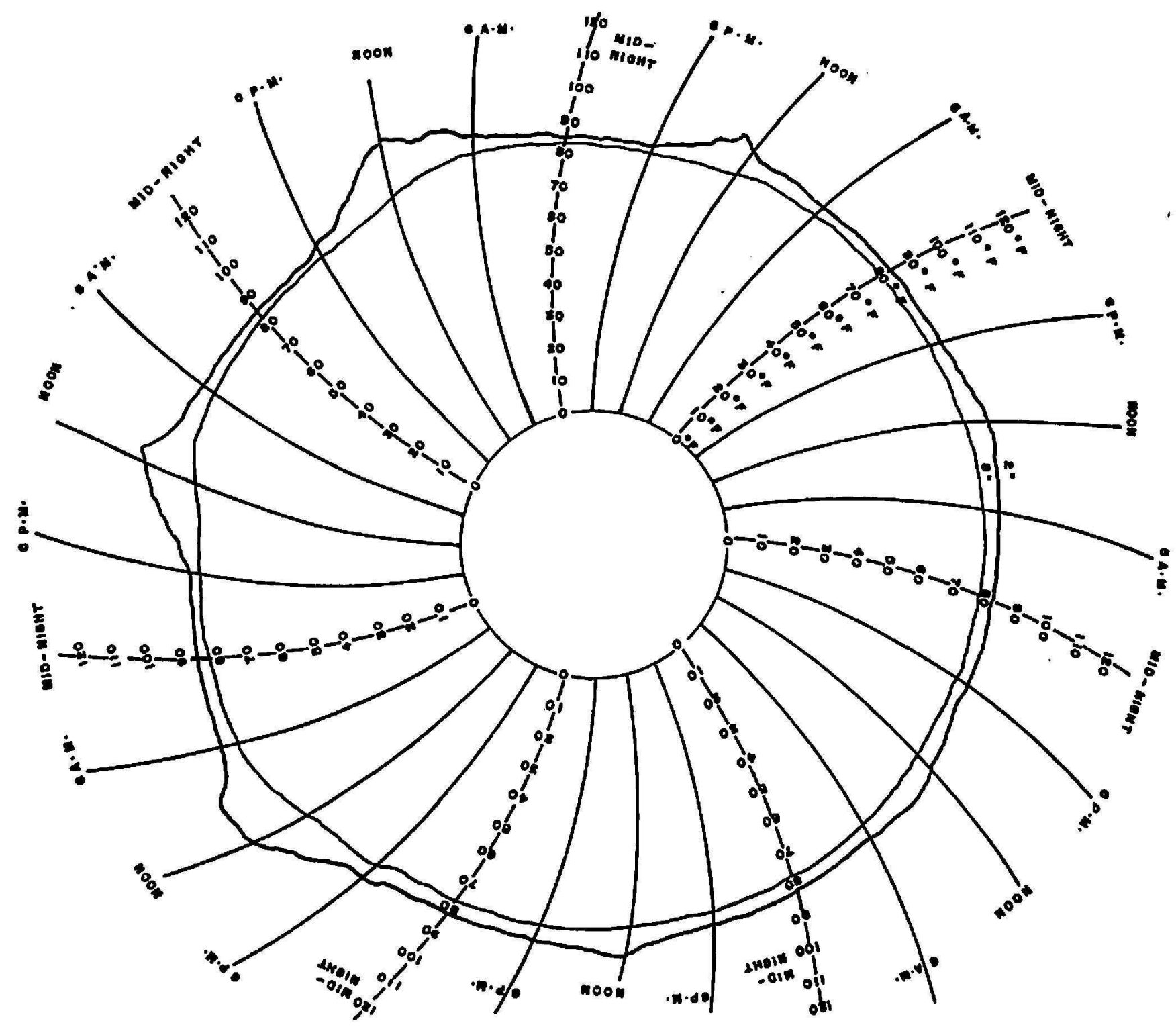

Fig. 2.-Time-course of soil temperature at 2- and 8-inch depths, typical of clear days. (Graph obtained at Rfo Piedras for March 25 to 31, 1971).

atmosphere is cooler than the soil. Thus, there is a daily rise and a daily fall in soil temperature". At Lajas and Fortuna, the surface 2 inches of soil becomes cooler than the subsurface 8 inches during the night. At Rio Piedras, because the air humidity is higher, the air temperature gradient is less steep at night and offers a resistance to the flux of heat into the atmosphere. The surface soil remains therefore, slightly warmer than the subsurface (about 2 degrees). However, on clear days at Río Piedras, the minimum soil tem- 
perature at 2- and 8-inch depths becomes nearly equal. This may be observed in figure 2 at nightime, where the time-course of soil temperature at 2 and 8 inches of depth was recorded for the week March 25 to 31, 1971. On nights following rainy days air humidity damps out the heat flux into space

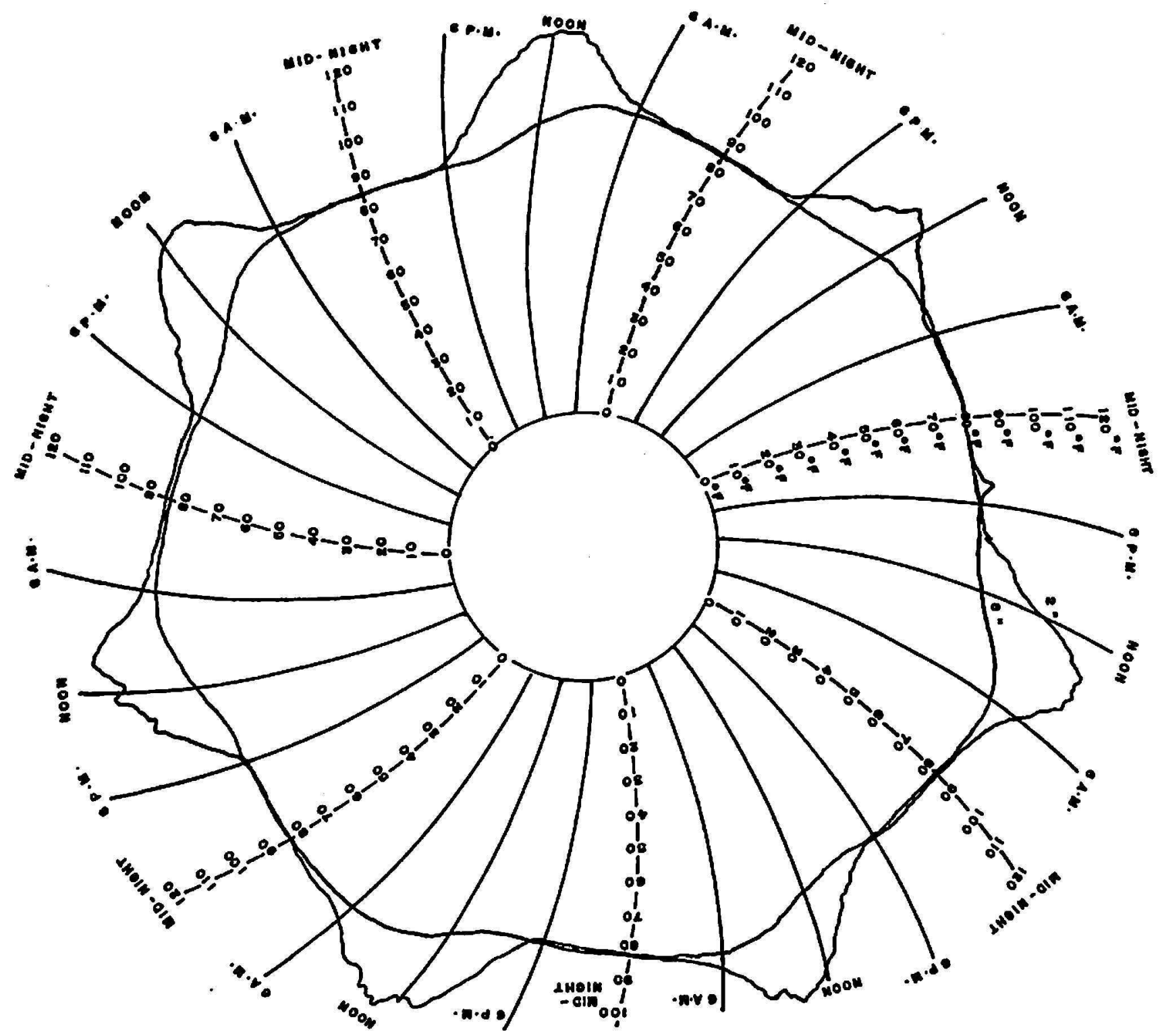

Fro. 3. - Time-course of soil temperature at 2- and 8-inch depths, typical of rainy days. (Graph obtained at Río Piedras for October 1 to 7,1970 ).

and soil temperature at 2 inches remains warmer than at 8 inches. Thus figures 2 and 3 present a typical contrast between clear and rainy days.

At the three locations, the minimum temperature of the air was always cooler than at the 2- and 8-inch soil depths. However, this is not quite true at the soil surface itself between 5 A.M. and 7 A.M., especially at Lajas and Fortuna.

Seasonal variations in soil temperatures follow the same general pattern 
as variations in air temperature. During the warmer months, higher soil temperatures are evident. Although no evidence is presented here, minimum air temperature lags behind minimum soil temperature possibly by an hour or two. While minimum soil temperature occurs just before six in the morning, minimum air temperature occur between 7 A.M. and 8 A.M. In the same manner, minimum temperature in the subsurface ( 8 inches) lags behind the 2-inch minimum temperature (fig. 2).

Thus it is at the soil-air interface where the most drastic changes in tempcrature occur, especially in bare soils.

Considering that air tempcrature is similar at the three locations, the evidence seems to indicate that rainfall or irrigation is probably one of the major determinants as to the differences in soil temperature between Lajas and the other two locations. At Lajas, the soil surface gets warmer during the day than either at Río Piedras or Fortuna, though it also cools more during the evening. Some of the differences in soil conditions between Lajas and Fortuna might perhaps explain in part the soil temperature differences between these two locations. The soils at Lajas are heavier, with predominance of small pores, and not so permeable as those at Fortuna.

\section{SUMMARY}

Soil temperature data at Rio Piedras in the north, Lajas in the southwest, and Fortuna in the south, are given in this paper for the 5-year period 196367. Seasonal variations in soil and air temperatures follow distinct patterns somewhat, depending on the nature of the soil cover and rainfall.

Mean maximum and minimum temperatures at the 2-inch depth, respectively, are: Río Piedras, $96.2^{\circ} \mathrm{F}$. and $79.6^{\circ} \mathrm{F}$; Lajas, $102.1^{\circ} \mathrm{F}$. and $69.0^{\circ} \mathrm{F}$; and Fortuna, $93.2^{\circ} \mathrm{F}$. and $79.1^{\circ} \mathrm{F}$. The corresponding soil temperatures at the S-inch depth, respectively, are: Río Piedras, $80.5^{\circ} \mathrm{F}$. and $77.4^{\circ} \mathrm{F}$; Lajas, $83.4^{\circ} \mathrm{F}$. and $77.8^{\circ} \mathrm{F}$.; and Fortuna, $85.7^{\circ} \mathrm{F}$. and $82.7^{\circ} \mathrm{F}$.

The differences and trends of soil temperature at 2-inch and 8-inch depths can find adequate explanation when soil moisture and soil cover are considered. However, the differences between maximum and minimum soil temperatures at 8 inches of depth are roughly one fifth of the corresponding ones at the 2-inch depth.

The maximum and minimum air temperature at Lajas, Fortuna and Río Piedras are much more similar to each other than the corresponding soil temperature, especially at the 2 -inch depth. This is mainly because air temperature is rather measured on a macro and integrating scale while soil temperature measurements exhibit localized effects of soil cover and soil moisture.

It was found that highly significant 2 -inch soil-air temperature relationships are evident under bare soil conditions. The same relationships were not significant under sod cover at Fortuna. 


\section{RESUMEN}

En este trabajo se presentan datos sobre la temperatura del suelo en tres localidades en Puerto Rico, a saber, Río Piedras en el norte, Lajas en el suroeste y Fortuna en el sur, para el periodo incluído entre los años 1963 al 1967.

Las variaciones estacionales en la temperatura del suelo y del aire siguen patrones bastante bien definidos dependiendo de la naturaleza de la cubierta del suelo y de la lluvia.

Se registraron las siguientes temperaturas máximas y mínimas, respectivamente, en las 2 pulgadas superficiales del suelo: en Río Piedras, $96.2^{\circ} \mathrm{F}$. y $79.6^{\circ} \mathrm{F}$.; en Lajas, $102.1^{\circ} \mathrm{F}$. y $69.0^{\circ} \mathrm{F}$; y en Fortuna, $93.2^{\circ} \mathrm{F}$. y $79.1^{\circ} \mathrm{F}$. Las temperaturas correspondientes a una profundidad de 8 pulgadas en el suelo fueron como sigue: en Río Piedras, $80.5^{\circ} \mathrm{F}$. y $77.4^{\circ} \mathrm{F}$; en Lajas, $83.4^{\circ} \mathrm{F}$ y $77.8^{\circ} \mathrm{F}$.; y en Fortuna, $85.7^{\circ} \mathrm{F}$. y $82.7^{\circ} \mathrm{F}$. Las diferencias y tendencias observadas en cuanto a la temperatura del suelo tanto a 2 pulgadas de profundidad como a 8 pueden explicarse cuando se considera la humedad del suelo y la cubierta vegetal. Sin embargo, las diferencias entre las temperatura máximas y minimas del suelo a 8 pueden pulgadas de profundidad son como la quinta parte de las correspondientes a 2 pulgadas de profundidad.

Las temperaturas máximas y minimas del aire en Lajas, Fortuna y Río Piedras son mucho más similares entre sí que las temperaturas correspondientes del suelo, especialmente a 2 pulgadas de profundidad. Esto puede atribuírse mayormente al hecho de que la temperatura del aire se mide en una escala mayor e integradamente mientras que la del suelo refleja efectos localizados debidos a la humedad y a la cubierta vegetal.

Se encontraron relaciones altamente significativas entre la temperatura del suelo a 2 pulgadas de profundidad y la del aire cuando el suelo no tenía cubierta vegetal alguna. La misma relación no fue significativa en al caso de Fortuna, donde el suelo estabe cubierto de yerbas.

\section{LITERATURE CITED}

1. Baver, L. D., Soil Physics, 3rd ed., John Wiley and Sons, Inc. New York, N.Y., chapter 10, 362-84, 1956.

2. Beauchamp, E. G., and Lathwell, D. J., Root temperature effects on the early development of maize, Plant and Soil 26: 224-34, 1967.

3. Lugo-López, M. A., Pérez-Escolar, R., Acevedo, G. and Juárez, Jr., J., Nature and properties of major soils of Lajas Valley, Agr. Exp. Str. Univ. P.R. Bull. $149,1959$.

4. Nelson, L. E., Effect of root temperature variation on growth and transpiration of cotton seedlings, Agron. J. 59: 391-5, 1967.

5. Roberts, R. C., Soil Survey of Puerto Rico. USDA in cooperation with Univ. P.R. Agr. Exp. Sta. 1942.

6. Shaw, B. T. (Ed.), Soil Physical Conditions and Plant Growth, Agronomy: A series of Monographs. II. Academic Press, Inc. New York, N.Y., chapter 5, pp. 303-480, 1952.

7. Soil Survey Staff, USDA Soil Conservation Service, Soil Survey Investigations Report No. 12, August 1967. 